\title{
VIOLETTA WRÓBLEWSKA
}

\section{„POMNIKI FOLKLORU”, CZYLI ANEGDOTY STUDENCKIE CZASÓW PRL-U W INTERNECIE}

Określenie ,pomniki folkloru” w odniesieniu do tradycyjnych form przekazu wywodzących się z kultury ludowej, a obecnie funkcjonujących w Sieci zaproponował Michaił D. Alekseevsky ${ }^{1}$. Rosyjski badacz, wyjaśniając swoje stanowisko w tej sprawie, stwierdził, że: [...] w internecie można znaleźć i byliczki, i czastuszki, i bajki magiczne. Jednak wszyst-
kie one są „pomnikami folkloru”, które trafiły do sieci z książek czy archiwów folklory-
stycznych. Nie jest to żywa tradycja funkcjonowania folkloru, a jedynie jej odbicie. Nie-
wykluczone, że z czasem wiejskie kobiety będa przesyłać sobie nawzajem teksty zaklęć
pocztą elektroniczną czy wykonywać czastuszki w trakcie wideokonferencji, ale na to
należy jeszcze poczekać ${ }^{2}$.

Idąc wskazanym przez cytowanego autora tropem, warto zadać pytania, czy powszechnie dostępne cyfrowe zasoby folkloru z przeszłości stanowią jedynie nieuporządkowany magazyn różnych rzeczy, w którym z trudem, z racji braku odpowiednich narzędzi i nadmiaru obiektów, porusza się współczesny badacz kultury, czy może rola internetu w tej kwestii jest bardziej złożona? Przychylam się zdecydowanie do drugiej z przedstawionych możliwości, o czym przekonują przeprowadzone przeze mnie badania dotyczące anegdoty studenckiej czasów PRL-u. Zasób tekstów tego rodzaju oraz trudny moment historyczny, którego dotyczą, wydawały mi się bardzo interesujące z kilku powodów. Wskazany okres jest zamknięty w wyraźnie określonych granicach czasowych (1952-1989), co daje możliwość objęcia go całościowym spojrzeniem i sprzyja większej wiarygodności poczynionych ustaleń. Jednocześnie, chociaż wybrana epoka już minęła, nadal żyje wiele osób, które pamiętają mechanizmy funkcjonowania panującego wtedy systemu polityczno-społecznego i realia kulturowe, dzięki czemu można jeszcze liczne przekazy odtworzyć oraz skonfrontować z materiałami dostępnymi na ten temat w publikacjach oraz w Sieci. Internet w tym zakresie okazuje się nieocenionym źródłem, bowiem w PRL-u nie istniał jego odpowiednik umożliwiający bieżące utrwalanie funkcjonującego folkloru. Dzięki współczesnym zasobom cyfrowym nie tylko docieramy do zapomnianych opowieści, owych ,pomników folkloru”, ale poznajemy ich konteksty wykonawcze. Narracje odnoszące się do wydarzeń sprzed kilkudziesięciu lat opatrzone są nierzadko komentarzem, zawierają dane na temat czasu i miejsca akcji oraz przedstawionych osób, co wzbogaca naukowe rozważania o istotne szczegóły, dające się łączyć z opisem szeroko rozumianych reguł komunikacyjnych i „symbolicznych reguł życia społecznego" 3 . Ponadto interesujące mnie opowieści niejednokrotnie zawierają oceny, które ujawniają zmiany, jakie zaszły w postrzeganiu rzeczywistości wpisanej $\mathrm{w}$ studenckie historie. Na podstawie różnorodnych danych można rekonstruować zawarty w anegdotach obraz PRL-u, a jednocześnie dokonywać zestawień porównawczych między dawnymi i nowymi przekazami, obserwując ich

${ }^{1}$ M. D. Alekseevsky, Internet $w$ folklorze czy folklor $w$ internecie? Wspótczesna folklorystyka rosyjska i rzeczywistość wirtualna, przeł. M. Goszczyńska, [w:] Netlor. Wiedza cyfrowa tubylców, red. P. Grochowski, Toruń 2013,s. 20. Artykuł w oryginalnej wersji językowej ukazał się w 2010 roku.

${ }^{2}$ Ibidem.

3 M. Derda-Nowakowski, Komunikacja spoteczna w internecie. Problemy badawcze, [w:] Oblicza komunikacji 1. Perspektywy badań nad tekstem, dyskursem i komunikacja, t. 2, red. I. Kamińska-Szmaj, T. Piekota, M. Zaśko-Zielińska, Kraków 2006, s. 632. 
ewolucję - formalną, semantyczną, jak również kulturową, zwłaszcza w zakresie pełnionych funkcji. Jednym słowem, w wypadku niedawnej przeszłości internet nie przechowuje jedynie archiwalnych materiałów, ale niejednokrotnie je ocala, nawet jeśli nie zawsze w pełnej postaci. Pozwala przy tym na obserwowanie kulturowej zmiany, która zachodzi w ich odbiorze i ocenie, co doskonale uświadamia lektura anegdot studenckich funkcjonujących w obiegu głównie przed 1989 rokiem.

Omawiany gatunek sam w sobie jest interesujący. Niezależnie od czasu wstępowania, należy do folkloru środowiskowego, za który można uznać w tym konkretnym wypadku nieoficjalną, spontaniczną i powielaną ustną bądź pisaną twórczość studentów ${ }^{4}$. Zazwyczaj za anegdoty uważa się krótkie przekazy prozą o zabarwieniu humorystycznym, nierzadko traktowane przez informatorów i odbiorców jako autentyczne, o czym zapewniają formuły charakterystyczne również dla legend miejskich, np. „Ta historia zdarzyła się mojej koleżance” bądź „Mój znajomy z akademika opowiedział mi...”.

Anegdoty studenckie, w przeciwieństwie do żartobliwych historyjek funkcjonujących wśród innych grup społecznych, są skoncentrowane na prezentacji żakowskiej codzienności w jej najbardziej barwnych przejawach ${ }^{5}$. Do tematów najchętniej podejmowanych $w$ tych przekazach należą niezwykłe zdarzenia rozgrywające się w akademikach oraz w salach wykładowych. We wskazany nurt wpisują się „klasyczne" opowieści znane w całej Polsce. Ich przykładem może być historia o pijanych żakach, którzy wyrzucili przez okno domu studenckiego kolegę w kartonie z napisem „Misja na Marsa”, a następnie zamierzali wypchnąć kolejnego z biesiadników w drugim pudle z napisem „Misja ratunkowa", ma opowieść o egzaminie, w czasie którego wykładowca wyrzuca przez okno indeks, obiecując zaliczenie temu studentowi, który zdąży go złapać ${ }^{7}$. Można by przywołać wiele innych przykładów tego rodzaju narracji, o czym pisał m.in. Paweł Łuczeczko ${ }^{8}$, ale nie zmienia to faktu, że wszystkie charakteryzują się zaskakującą pointą, poświadczającą nieprzeciętne zdolności żaków zaangażowanych w oswajanie procesu studiowania ${ }^{9}$. W świetle anegdot ów proces polega na prowadzeniu ciągłej ,,walki” z szeroko rozumianym systemem akademickim $-\mathrm{z}$ egzaminatorami, wykładowcami, a nawet $\mathrm{z}$ paniami $\mathrm{z}$ portierni czy z dziekanatu, w czym widać charakterystyczną dla całego folkloru zasadę opozycyjności „swój - obcy”.10 „Swój” w omawianym przypadku to zazwyczaj przedstawiciel braci studenckiej, a „obcy” - najprościej mówiąc, każdy inny, czyli niestudent, z którym przyszło się zmierzyć młodzieży w trakcie edukacji. Binarna wizja świata, jak wiadomo, służy budowaniu wyrazistych ocen, w których świetle

${ }^{4}$ Zob. definicję kultury studenckiej: V. Wróblewska, Czy warto badać kulturę studencka na UMK? Wprowadzenie, [w:] Kultura studencka. Z badań folklorystycznych na Uniwersytecie Mikotaja Kopernika, red. V. Wróblewska, Torun 2015, s. 11-12.

${ }^{5}$ Zob. szerzej na ten temat: Kultura studencka. Z badań folklorystycznych...; Kultura studencka. Zjawisko - twórcy - instytucje, red. E. Chudziński, Kraków 2001; T. Skoczek, Kultura studencka. Mit i rzeczywistość, Kraków 1988.

${ }^{6}$ Rodzynki studenckie, czyli co się wyktada na wyktadach, wyb. M. Kędziora, Gliwice 2008, s. 168.

P. Łuczeczko, „Z Trobriandów do Torunia”..., czyli funkcjonalna analiza studenckiej anegdoty. $Z$ badań nad folklorem wspótczesnym studentów UMK w Toruniu, [w:] Z trzeciego brzegu Wisty. Szkice z antropologii Torunia, red. H. Czachowski, O. Kwiatkowska, A. Mianecki, A. Trapszyc, Torun 2007, s. 105.

${ }^{8}$ P. Łuczeczko, „Z Trobriandów do Torunia”..., s. 95-111; idem, Żebracza kartka, studencka anegdota i tańcuch szczęścia, czyli o pożytkach uprawiania folklorystyki przez socjologów, [w:] Folklor w dobie Internetu, red. G. Gańcarczyk, P. Grochowski, Toruń 2009, s. 145-160.

${ }^{9}$ Cechy anegdoty dokładnie omówił P. Łuczeczko. Idem, „ZZ Trobriandów do Torunia”..., op. cit..., s. 97-98.

${ }^{10}$ J. S. Bystroń, Wierzenia o obcych, [w:] idem, Tematy, które mi odradzano. Pisma etnograficzne rozproszone, wyb. i oprac. L. Stomma, Warszawa 1980, s. 320-334. 
zdecydowanie lepiej wypadają studiujący niż ich przeciwnicy, zazwyczaj niedorównujący im w zakresie pomysłowości w rozwiązywaniu problemów, co przyczynia się do wzmacniania wizerunku i tożsamości żakowskiej wspólnoty. Widoczna w tekstach intencja ośmieszania egzaminatorów i nauczycieli służy oswajaniu akademickiej rzeczywistości, która dzięki temu wydać się może mniej groźna i bardziej przewidywalna. Badacze studenckich anegdot przypisują im również wiele innych funkcji, np. ludyczną, mitotwórczą, obrzędową (rytualną), stratyfikacyjną, informacyjną (komunikacyjną), kompensacyjną i kulturotwórczą (normo- i wzorcotwórczą) ${ }^{11}$.

Ponieważ problematyka współczesnych anegdot studenckich systematycznie pojawia się $\mathrm{w}$ badaniach folklorystycznych ${ }^{12}$, więc nie ma potrzeby referowania wszystkich kwestii z tym związanych. W powyższym kontekście rodzą się wspomniane już przeze mnie pytania o możliwość dotarcia do dawniejszych zasobów tego rodzaju opowieści pozwalających lepiej poznać kulturę studencką minionych epok, kontekst wykonawczy, jak też różnice między dawnymi a nowymi przekazami i ich związek z czasem, w którym funkcjonowały. Wiadomo bowiem, że „tekst folkloru niesie ze sobą treści, będące [...] odbiciem autentycznych, często nieformalnych, nieoficjalnych i niejawnych relacji społecznych"13. Ponadto, jak stwierdził Jan Kajfosz, „Każda epoka ma przecież swe ulubione tematy, które przyciągają uwagę żyjących w niej ludzi i które w następnych epokach mogą być odrzucane czy zapomniane; mogą też powracać za jakiś czas w zmienionej postaci [...]" $]^{\prime 14}$.

Przebadane przeze mnie studenckie anegdoty to około 100 przekazów, pozyskanych w latach 2014-2016 przede wszystkim ze stron internetowych, głównie z tzw. forów (dyskusje obejmują okres 2005-2016), w mniejszym stopniu z dostępnych publikacji dotyczących kultury studenckiej, w tym $\mathrm{z}$ antologii tekstów ${ }^{15}$, a także $\mathrm{z}$ niepublikowanych materiałów ${ }^{16}$ oraz $\mathrm{z}$ własnego archiwum anegdot studenckich. W świetle tych materiałów śmiało można stwierdzić, że w czasach minionych królowały opowieści zbliżone do tych zapisywanych współcześnie ${ }^{17}$, a więc koncentrujące się na opozycjach student - egzaminator, dziekan czy pani z administracji. Zmianie ulegają jedynie przedstawione realia społeczno-kulturowe. Pewnej modyfikacji podlega także zestaw „obcych”, co pozostaje w silnym związku z kontekstem epoki. Ponieważ ukazany schemat działania pomysłowego studenta jest analogiczny w repertuarze z 2 połowy XX wieku, jak i początku XXI wieku, dla przykładu przywołam tylko dwie PRL-owskie anegdoty potwierdzające tę prawidłowość. Różnica między dawnymi a nowymi przekazami ujawnia się jedynie na poziomie świata przedstawionego, bowiem w wypadku starszych wariantów występują zjawiska, które dla współczesnych odbiorców mogą być już niezrozumiałe:

${ }^{11}$ P. Łuczeczko, „Z Trobriandów do Torunia”..., op. cit., s. 98-110.

${ }^{12}$ Zob. m.in. P. Łuczeczko, op. cit.; idem, Żebracza kartka, studencka anegdota i tańcuch szczesścia... op. cit., s. 145-160; A. Gnatowska, Anegdota jako integralna część kultury studenckiej, [w:] Kultura studencka. Z badań folklorystycznych..., op. cit., s. 161-182; M. Kowalska, Wspomnienia $i$ anegdoty absolwentów UMK jako świadectwa codzienności, [w:] Kultura studencka.... op. cit., s. 183-203.

${ }^{13}$ P. Łuczeczko, ,Z Trobriandów do Torunia”..., op. cit., s. 15

${ }^{14}$ J. Kajfosz, Folklor jako tekst w obiegu i jego potencjat konstruowania rzeczywistości, [w:] Nowe konteksty badań folklorystycznych, red. J. Hajduk-Nijakowska, T. Smolińska, Wrocław 2011, s. 59.

${ }^{15}$ Do towarzysza Mikołaja Kopernika, czyli studencka anegdota, zeb. i oprac. M. Andrzejewski, Gdańsk 2013; Rodzynki studenckie...

16 J. Kruk, „Folklor studentów UMK”, praca magisterska napisana pod kierunkiem prof. dra hab. J. M. Kasjana w Instytucie Filologii Polskiej na Wydziale Filologicznym UMK, Toruń 1993. Praca dostępna w Archiwum prac magisterskich i doktorskich napisanych pod kierunkiem prof. J. M. Kasjana znajdującym się w Zakładzie Folklorystyki i Literatury Popularnej w Katedrze Kulturoznawstwa UMK w Toruniu; nr syg. K/202.

${ }^{17}$ Zob. P. Łuczeczko, „Z Trobriandów do Torunia”... ,op. cit. 
Prodziekan Stanisław M. komentuje wiarygodność podania studenta o przedłużenie sesji egzaminacyjnej:

- Czwarty raz uśmierca Pan swojego dziadka.

- Student odpowiada:

- Mój dziadek to taki Wańka wstańka ${ }^{18}$.

Studentka ma kłopoty z zaliczeniem języka rosyjskiego. Podchodzi do tego zaliczenia już czwarty raz. Lektorka spostrzega kolczyki studentki w kształcie sierpa i młota.

- Jeśli ktoś nosi takie kolczyki, to powinien mieć zaliczenie ${ }^{19}$.

W pierwszym przykładzie mamy do czynienia $\mathrm{z}$ odwołaniem do popularnej w latach 70. XX wieku radzieckiej zabawki, zwanej wańką-wstańką, niekiedy bańkąwstańką, której nie można było przewrócić, gdyż jej kulisty kształt i ciężar umieszczony wewnątrz plastikowej postaci gwarantowały powrót do pozycji poziomej ${ }^{20}$. Z kolei druga opowieść nawiązuje do obowiązkowej na wszystkich etapach edukacji szkolnej w czasach PRL-u nauki języka rosyjskiego i propagowanych powszechnie symboli władzy radzieckiej. Chociaż historyczne realia mogą być dla współczesnych odbiorców nie do końca zrozumiałe, sama zasada ukazywania relacji student - egzaminator, w której pierwszy zdecydowanie wypada korzystniej niż drugi, pozostaje obecnie taka sama. Można mówić w tym zakresie o pewnej ciągłości kultury studenckiej, niezależnej od zmieniających się okoliczności politycznych czy kulturowych. Powyższa uwaga odnosi się również do pozostałego zgromadzonego przeze mnie materiału anegdotycznego z czasów PRL-u. Trzeba jednak dodać, że wraz z zanikiem elementów rzeczywistości, do których nawiązują narracje, omawiane opowieści wypadły z żywego obiegu, ponieważ przestały się wiązać z życiem studenckim. Obecnie funkcjonują one raczej jako kawały, rzadziej anegdoty o charakterze historycznym, co najlepiej obrazuje przykład dotyczący represji z lat 60 . XX wieku:

W marcu 1968 zapytano chłopa:

- Poślecie syna na studia, na uniwersytet?

- Nie poślę, sam go będę bił ${ }^{21}$.

Niewykluczone, że niniejszy kawał, czyli gatunek z założenia odbierany jako przekaz fikcyjny, mógł powstać z wcześniejszej anegdoty, a więc opowieści uznawanej za prawdziwą, która uległa modyfikacji (m.in. pozbawienie formuł prawdziwościowych, wskazania kontekstu zasłyszenia historii) w efekcie upływu czasu i zmiany rzeczywistości, do której przykład się odnosił. Jego treści obecnie nie daje się już zweryfikować, jest traktowana jako odległa, trudno uwierzyć w jej autentyczność, tym samym cały przekaz przekształca się w dowcip. Powyższa teza wymaga dalszych badań, jednak zdają się ją potwierdzać opowieści odnoszące się do innego elementu PRLowskiej rzeczywistości studenckiej, tzw. praktyk robotniczych ${ }^{22}$, które musiał odbyć w czasie wakacji każdy student przed rozpoczęciem pierwszego roku. Przykładowa historia tego typu ukazuje pracujących fizycznie studentów oraz przechodzącą obok

\footnotetext{
${ }^{18}$ Ibidem, s. 27.

${ }^{19}$ Ibidem, s. 114

${ }^{20} \mathrm{http} / / /$ dydaktyka.fizyka.umk.pl/zabawkil/files/mech/wanka-pl.html [dostęp: 19.06.2016].

${ }^{21}$ Czytaj więcej na http://facet.interia.pl/obyczaje/historia/news-partia-rzadzi-partia-radziz-czego-smiano-sie-w-prl-u,nId,1032883\#utm_source=paste\&utm_medium=paste\&utm_campaign =firefox [dostęp: 6.05.2016]. We wszystkich przykładach pochodzących z internetu zachowano pisownię oryginalną.

${ }_{22}$ Zasady odbywania praktyk, ustanowionych po wydarzeniach 1968 roku, regulowała Uchwała nr 24 Rady Ministrów z dnia 16 lutego 1970 roku w sprawie organizacji praktyk robotniczych studentów szkół wyższych. Zob. „Monitor Polski” 1970, nr 7, poz. 64; modyfikacja nastąpiła w 1989 roku - zob. Rozporządzenie Rady Ministrów z dnia 22 marca 1989 roku zmieniające rozporządzenie w sprawie praktyk studenckich robotniczych i zawodowych, „Dziennik Ustaw Polskiej Rzeczpospolitej Ludowej” 30 marca 1989, nr 17, poz. 96.
} 
nich kobietę, która straszy idące z nią dziecko, że gdy nie będzie się uczyło, w przyszłości skończy tak jak obserwowani młodzi ludzie ${ }^{23}$.

Jeśli anegdota studencka nie podlega przekształceniu w dowcip, staje się opowieścią o charakterze historycznym, która sporadycznie pojawia się w obiegu, zazwyczaj w internecie, częściej w codziennej sytuacji nieoficjalnej, np. w trakcie uroczystości rodzinnych. Przykładem może być zasłyszana przeze mnie w czasie jednego ze spotkań tego typu (kwiecień 2016 r.) anegdota opowiedziana przez starsze małżeństwo, które studiowało w latach 60. XX wieku w Toruniu. Punktem wywoławczym uruchamiającym narrację wspomnieniową okazała się wypowiedź jednej z wnuczek dotycząca zdawanych w czasie sesji egzaminów. Słowo „zdawać” okazało się zapalnikiem, wywołującym skojarzenia odnoszące się do życia w akademiku w czasach PRL-u. Miała wtedy krążyć w obiegu anegdota dotycząca studentów-kpiarzy, którzy na zadawane im przez kolegów pytanie: „Co zostało ci do zdania?”, odpowiadali: „Tylko pościel”. Współcześnie tego typu przekaz może wydać się nie do końca czytelny, ale kiedy poznamy realia z minionego okresu, zyskuje on nowe znaczenia. W latach 60 . XX wieku większość studentów mieszkała w akademikach, które musiała opuszczać na czas wakacji. Przed ich wyjazdem do obowiązków należało oddanie klucza i wypożyczonej na rok akademicki pościeli, co nazywano „zdawaniem” (pokoju, pościeli ${ }^{24}$ ). Stąd zabawa słowem - zdawać - egzamin, pokój, pościel.

Wraz ze zmianą systemu politycznego zniknęły również inne bardzo charakterystyczne dla omawianej epoki realia społeczno-kulturowe, często stanowiące temat spontanicznych wypowiedzi studenckich. Do takich „elementów” należą milicja obywatelska oraz studium wojskowe. Obie instytucje były mocno związane z systemem totalitarnym, z kontrolą i represją, więc wraz z ich likwidacją, jak również transformacją opowieści na ich temat zostały wyparte ze studenckiego repertuaru. Mimo że znaczna część przekazów o milicjantach przekształciła się w przekazy o policjantach, bez uszczerbku dla znaczenia narracji, nie zachowały się zbyt licznie PRL-owskie opowieści traktujące o kontaktach żaków z przedstawicielami władzy, gdyż obecnie relacje między obiema grupami znacznie zmieniły swój charakter i reprezentanci sił porządkowych rzadziej wpisują się w anegdotyczną grupę „obcych”. Przed 1989 rokiem opowieści o spotkaniu z milicją miały zdecydowanie polityczny podtekst i niewykluczone, że były traktowane jako symboliczna forma walki z systemem ${ }^{25}$, w której student prezentował się jako (mimowolny) opozycjonista. Powyższej tezy dowodzą dwa kawały, prawdopodobnie również wywodzące się z anegdot, u których podstaw mogłyby leżeć przeżycia jednostkowe, ale obecnie trudno ten fakt zweryfikować:

Zomowcy pobili studenta, który na ulicy rozrzucał ulotki.

Po jakimś czasie zauważyli, że kartki były puste.

- Dlaczego pan rozrzucał puste kartki? - pytają.

- Ludzie i tak wiedzą, co ma być na nich napisane ${ }^{26}$.

Zatrzymuje milicjant studenta, legitymuje go, otwiera dowód i czyta:

- Widzę że nie pracujemy - mówi milicjant.

- Niieee pracujemy - potwierdza student.

- Opier**my się .. - mówi milicjant.

- Opier**my się - potwierdza student.

- O!? Studiujemy - rzecze policjant.

- Nieeee, tylko ja studiuję... - odpowiada student ${ }^{27}$.

${ }^{23}$ Zob. V. Wróblewska, op. cit., s. 19-20.

${ }^{24}$ Współcześnie spotykamy się z formą zdawania pokoju, ale nie pościeli.

${ }^{25} \mathrm{O}$ folklorze politycznym jako formie kontestacji pisał w swej interesującej monografii Wojciech Łysiak. Zob. tenże, Wielka kontestacja. Folklor polityczny w PRL, Poznań 1998.

${ }^{26}$ http://kawaly.tja.pl/o-prl.html?st=2 [dostęp: 17.08.2014]; zob. też: http://facet.interia.pl/ obyczaje/historia/news-partia-rzadzi-partia-radzi-z-czego-smiano-sie-w-prl-u,nId,1032883 [dostęp: 26.05.2016]. 
Warto zaznaczyć, że powyższy dowcip daje się odnieść również do czasów współczesnych, ale pewne elementy wskazują, że jest to jednak historia z przeszłości. Mowa o „otwieraniu dowodu”, czyli o funkcjonowaniu dokumentu tożsamości w formie zielonej, kilkustronicowej książeczki, którą obecnie zastąpiła forma plastikowej karty zawierającej podstawowe dane właściciela. Ponadto współcześnie wielu policjantów ma ukończone studia wyższe, co w czasach PRL-u należało do rzadkości.

Zdecydowanie ciekawej wypada na tym tle grupa opowieści o tzw. studium wojskowym, które było obowiązkową częścią edukacji na wszystkich kierunkach i polegało m.in. na odbywaniu raz w tygodniu całodziennych zajęć z szeroko rozumianej wojskowości i obronności kraju. Charakter, cel i przebieg zajęć tego typu regulowało Zarządzenie Ministra Obrony Narodowej z 21 lipca 1959 roku - „w sprawie wojskowego szkolenia studentów" ${ }^{, 28}$. Z reguły zajęcia takie wpisane były w program IV lub $\mathrm{V}$ roku ${ }^{29}$, czyli trwały rok, niekiedy 3 lata w wymiarze około 500 godzin, a ich niezaliczenie skutkowało nieukończeniem studiów niezależnie od wyników z pozostałych przedmiotów. Były to przede wszystkim wykłady o charakterze propagandowym oraz ćwiczenia militarne, w związku z tym nie brakowało na nich różnorodnych form indoktrynacji. Istotne jest to, że prowadzili je $\mathrm{z}$ reguły emerytowani wojskowi, tzw. frontowcy, co miało gwarantować pożądaną jakość treści przekazywanych młodzieży. W świetle zachowanych anegdot przedstawiciele wojska prezentuja się nader niekorzystnie, co może sprzyjać tezie, iż oddelegowywano do tej pracy mało rozgarniętych oficerów czy podoficerów, często nie do końca sprawnie posługujących się językiem polskim (internauci w swoich wspomnieniach z tego okresu nazywają ich „trepami”, ${ }^{30}$ ). Sprytni studenci wykorzystywali słabości kadry, ośmieszając ją na różne sposoby bądź też odnotowując niezliczone pomyłki językowe, co najlepiej obrazują same anegdoty:

Podczas przerwy w zajęciach jeden ze studentów napisał na tablicy: „Major F. to ch...”. Zobaczywszy, jak się go określa, oficer zażadał, żeby winny przyznał się do niecnego czynu. Oczywiście nikt nie zamierzał tego zrobić. Wówczas major oświadczył:

- Co, nikt nie chce się przyznać?! Przyjdę z dowódca Studium Wojskowego i wtedy zobaczymy.

Nie znalazłszy dowódcy, wrócił po 5 minutach sam. Ponieważ w międzyczasie napis został zmazany, major wziął kredę i napisał to, co było przedtem, po czym ponownie wyszedł. Tym razem wrócił już z dowódcą, któremu poskarżył się.

- Obywatelu pułkowniku, nikt nie chce powiedzieć, kto jest autorem tego wulgarnego napisu.

Pułkownik zrobił groźną minę i zapytał studentów.

- Kto to napisał?

- Pan major - odparli studenci.

Zdezorientowany pułkownik zwrócił się do majora:

- To prawda?

- Tak - musiał przyznać tamten ${ }^{31}$.

Starsi forumowicze pamietają...W czasie studiów mieliśmy szkolenie wojskowe. Rozśmieszało nas to czasami, więc z moją koleżanką bywałyśmy niesubordynowane, wygłupiałyśmy się na apelach. Pewnego razu nasz oficer szkoleniowy nie wytrzymał i wrzasnął do nas w obecności 200 studentów na apelu: „Jeżeli studentka W. i studentka R. nie przestaną się śmiać, to będą studentki miały stosunek nie tylko ze mną, ale z całym dowództwem!" Rżeli wszyscy jeszcze dobre pięć minut ${ }^{32}$.

${ }^{27} \mathrm{http} / / /$ dowcipnastrona.republika.pl/kawalyopolicjantachmilicjantach.htm [dostęp: 3.05.

2016]; ten sam zob. http://kawaly.tja.pl/o-studentach [dostep: 20.06.2016].

${ }^{28}$ isap.sejm.gov.pl/Download?id=WMP19590680350\&type $=2$

${ }^{29}$ Wszystkie studia miały charakter ciągły, zwykle trwały 5 lub 6 lat. 15. 04.2015].

http://korabita.salon24.pl/527230,cud-nad-wisla-a-studium-wojskowe-w-prl [dostęp:

${ }^{31}$ J. Kruk, op. cit., s. 31-32.

32 http://forum.gazeta.pl/forum/w,384,11333359,11333359,Studium_wojskowe.html [dostęp: 17.08.2014] 
Wczesne lata 70. Poranek. Zbiórka kompanii studenckiej na SW. Dowódca kompanii: „Wy sobie nie myślcie studenty, że oficerowie ze SW są organiczeni kulturalnie. Nie dalej jak wczoraj wszyscy oficerowie byli obowiązkowo na operetce »Ptasznik z trotylu «"33.

Początek wykładu, wojskowy sprawdza listę:

- Kowalski..

- Nie ma, wyszedł ze stolcem do toalety.

- To powiedzcie im obu, jak wrócą, że wpisałem im spóźnienie ${ }^{34}$.

Tego typu zdarzenia pamiętają i powielają również osoby znane ze świata współczesnej kultury, potwierdzając powszechność przedstawianych w anegdotach zjawisk, o czym świadczy wpis na forum poświęconym studium wojskowemu jednego z komentatorów:

[...] za młody jestem na studium wojskowe, ale parę lat temu Paweł Huelle poświęcił tej instytucji jeden z felietonów w GW. Było tam m.in. o tym, że ,jak ktoś nie chodził na zajęcia, to może je zaliczyć przez odbyt u kapitana XY w następnym semestrze...” i jeszcze: ,podczas pobytu w bunkrze panują ciężkie warunki - trzeba czerpać bieżacca wodę ze słoika..." i jeszcze anegdotka Bałtroczyka o studium wojskowym: Pytanie wykładowcy: Żołnierze, co emituje czołg? odpowiedzi są różne - spaliny, wodę, wodór (?!), a wykładowca ciągle powtarza „Nie, ponawiam pytanie - co emituje czołg?” Kiedy wszyscy już pałają żądzą, by usłyszeć odpowiedź co takiego emituje czołg, wykładowca stwierdza rezolutnie: „czołg emituje makieta...”35.

Oczywiście, należy mieć świadomość, że nie każdy prowadzący był gorliwym wyznawcą systemu i nie zawsze solidnie przykładał się do zajęć, o czym świadczą anegdoty przedstawiające łagodny obraz oficera uosabiającego figurę „obcego”. Trzeba zaznaczyć, że należą one jednak do rzadszych przypadków, jak następująca opowieść:

Otóż wyżej podpisana miała przyjemność odbyć najbezboleśniejsze chyba szkolenie wojskowe, jak PRL długi i szeroki. Kierownik studium, płk. Z., człowiekiem był nad wyraz przyzwoitym, a do tego wojskowości niechętnym. Ponieważ studium miało swą siedzibę w akademiku, wyżej podpisana zjawiała się na porannych zajęciach (ani jeden apel się nie odbył) w dresie i kapciach, a pobrawszy obecność kontynuowała sen. Na najbliższej przerwie wracała do łóżeczka, śniadanka itp., aby po 4 godzinach powtórzyć niecny proceder z pobieraniem obecności. Płk. Z. ocenił te działania na bdb $[\ldots]^{36}$.

Przywołane narracje, których można przytoczyć wiele, potwierdzają obecność opozycji „swój” i „obcy” w studenckiej anegdocie. Co jednak istotne, wszyscy „obcy”bez względu na to, czy jest nim wykładowca, wojskowy czy milicjant, wpisują się w szeroko rozumianą grupę edukatorów i kontrolerów, mających przewagę nad osobą niesamodzielną - w znaczeniu finansowym, zawodowym i społecznym - za jaką uchodzi student (pomijam studia zaoczne, na których edukację pobierały osoby pracujące).W większości przykładów żak wykazuje się jednak takim sprytem i inteligencją, że w świetle anegdot zdaje się zajmować wyższą pozycję niż przedstawiciele wymienionych grup reprezentujących władzę. W wypadku anegdot PRL-owskich można w tym upatrywać pewien rodzaj pośredniej manifestacji poglądów politycznych, piętnujących obowiązujący wtedy system, zwłaszcza gdy oponentem był szkoleniowiec

33 http://forum.gazeta.pl/forum/w,384,10331345,10366983,Re_co_tam_wykladowcy_stu diumwojskowe_to_byl_h.html [dostęp: 17.08.2014].

${ }^{34} \mathrm{http}: / /$ forum.gazeta.pl/forum/w,384,10331345,12328799,Re_co_tam_wykladowcystudium wojskowe_to_byl_h.html [dostęp: 17.08.2014]; zob. też http://forum.gazeta.pl/forum/w,50, 18562 047,18562047,pytanie_do_wojskowych. html\#p185 66237 [dostęp: 5.05.2016].

$35 \mathrm{http} / / /$ forum.gazeta.pl/forum/w,384,10331345,10375263,Re_co_tam_wykladowcy_stu dium_wojskowe_to_byl_h.html [dostęp: 17.08.2014].

${ }^{36} \mathrm{http} / / /$ forum.gazeta.pl/forum/w,12233,71561085,71601360,Studium_wojskowe.html [dostęp: 17.08.2014]. 
ze studium wojskowego czy milicjant. Dodajmy, że przedstawiciele drugiej grupy, o czym była mowa, rzadko występują w anegdotach typowo studenckich, być może $\mathrm{z}$ tego powodu, że kontakty $\mathrm{z}$ nimi dla omawianej grupy były dość sporadyczne, w przeciwieństwie do regularnych spotkań z wojskowymi. Z kolei milicjanci częściej występowali w dowcipach o szeroko pojmowanej grupie tzw. głupich (np. o sąsiadach, przedstawicielach innych nacji czy zawodów), opowiadanych niezależnie od środowiska, i w większości wypadków pojawiający się na drugim planie student łatwo daje się zastąpić jakąkolwiek inną postacią:

Studenci (blondynki, informatycy itd. - przyp. V.W.) w autobusie opowiadają kawały o milicjantach.

- Dlaczego milicjanci nie jedzą ogórków?

- Bo nie mogą włożyć głowy do słoika ${ }^{37}$.

Anegdoty typowo studenckie, a więc opowiadane przez studentów i o studentach, w przeciwieństwie do dowcipów czy opowieści komicznych innego typu, silnie łączą się z samym procesem studiowania i związanym z nim trybem życia, służąc oswajaniu towarzyszących im lęków. A ponieważ w życie studenta w PRL-u wpisanych było kilka charakterystycznych elementów oprócz nauki i zabawy, jak kontakt z milicjantami czy wojskowymi, i one stały się częścią folkloru. Przy okazji - i to w wielu wypadkach pewnie bezwiednie - anegdoty, ośmieszając typowo PRL-owskich „obcych”, stały się formą wspomnianej już symbolicznej walki z systemem, elementem kontestacji i oswajania wroga, co typowe dla folkloru politycznego, o czym pisał Wojciech Łysiak ${ }^{38}$. Przywołany badacz, charakteryzując liczne formy folkloru politycznego, nie wspomina o studentach jako jego twórcach, chociaż wiadomo, że żacy byli także zaangażowani w walkę z komunizmem ${ }^{39}$. Być może niedostatek materiału albo trudności związane z jego wyodrębnieniem z zasobów pochodzących od innych walczących z systemem grup nie pozwoliły na tego rodzaju omówienie. Internet, spełniając rolę archiwum, stwarza szansę na dotarcie do ulotnego studenckiego materiału, który nie jest przechowywany w innych zasobach archiwalnych, m.in. ze względu na nieznaczną wartość polityczną. Wartość taką miały opisane przez Łysiaka ulotki, broszury czy antykomunistyczne ballady satyryczne, które były tworzone, rozpowszechniane i przechowywane przez opozycyjne podziemie. W świetle zebranego i pokrótce scharakteryzowanego materiału „akademickiego" trudno mówić o szczególnym zaangażowaniu studentów w działalność opozycyjną, chociaż niektóre anegdoty wyraźnie wskazują na świadomą postawę prowokacji politycznej wobec prowadzących zajęcia, np. wobec pracowników studium wojskowego. Świadczy o tym choćby poniższy przykład mający charakter wspomnienia:

I oto mamy rok 1987: któryś „trep” przynudza o wojskowości polskiej, wygłaszając banały na temat przewodniej roli sił itp. itd. Jeden z dyżurnych „śmieszków” podnosi dwa palce $\mathrm{z}$ miną niewinnego debila:

- Obywatelu poruczniku, a co to był „Cud nad Wisłą"?

Kamień obrazy. Tu się o wojnie 1920 roku nie mówi, to godzi w bratnie sojusze i porządek społeczny (acz przypomnę, że poza studium wojskowym mówiono już wtedy o wszystkim swobodnie). Obywatel porucznik zalewa się purpurą jak burak, ale znajduje wyjście:

- Obywatelu studencie, nie wyznawajcie przesądów, nie było żadnego cudu, po prostu daliśmy bolszewikom w d[...].

${ }^{37}$ J. Kruk, op. cit., s. 87.

${ }^{38}$ W. Łysiak, op. cit.

39 Zob. np. artykuł napisany przez pracownika Wydziału Nauk Historycznych UMK, w oparciu o materiały archiwalne i przeprowadzone wywiady: W. Polak, NSZZ "Solidarność" na Uniwersytecie Mikotaja Kopernika w Toruniu w latach 1980-1989, http://www. solidarnosc.umk.pl/archiwum/polak.php [dostęp: 7.06.2016]. 
Tymi słowami ,trep” zaskarbił sobie pewne uznanie studenckiej braci. A i przed swoim dowództwem mógł się w razie czego wytłumaczyć - że stanął w obronie tradycji świeckiej i antyklerykalnej ${ }^{40}$.

Anegdotę o podobnym charakterze, tyle że w odniesieniu do milicji, przywołuje w swej pracy Paweł Łuczeczko:

Słyszałem też o profesorze $X$, że w czasach swoich studiów na UMK, gdy mieszkał w akademiku, zrobił z kolegami taki opozycyjny performance. Wywiesili któregoś dnia z okna pokoju w akademiku prześcieradło z wielkim napisem „DZIĘKUJEMY!” [śmiech]. Oczywiście dość szybko zainteresowały się tym odpowiednie służby, przyjechały, zabrały ich na komendę, przesłuchują - za co ci studenci tak bardzo dziękują... A oni na to, że świat jest po prostu piękny, gdy się studiuje - są za to po prostu światu wdzięczni ${ }^{41}$

Nie wydaje się jednak, aby jedynym albo nawet głównym celem podobnych do przytoczonej powyżej anegdoty było ośmieszanie przedstawicieli władzy. Jak powiedziano, istotą omawianych przekazów jest prezentacja trudów studiowania, z którymi doskonale radzi sobie sprytny żak, pokonujący wszystkich niestudentów, niezależnie od środowiska, które dane osoby reprezentują, czy od głoszonych przez nie poglądów. Można odnieść wrażenie, że milicjant i wykładowca ze studium wojskowego funkcjonują w opowieściach na tych samych prawach co zbyt wymagający profesor czy pani $\mathrm{z}$ portierni $\mathrm{w}$ akademiku utrudniająca wejście niezameldowanym tam osobom, czyli tzw. waletom. Wszystkich należy pokonać, bowiem reprezentują tych, którzy utrudniają bezstresowe ukończenie studiów. Tym samym skuteczność perswazyjna anegdot studenckich w zakresie oddziaływania politycznego wydaje się nieznaczna, chociaż trudno wyrokować o tym z perspektywy współczesności, gdyż - jak zauważa Łysiak - „Utwory folkloru politycznego tych lat odwołują się do realnych doświadczeń, które z biegiem czasu uległy daleko idącemu procesowi zacierania się wartości naczelnych, zatraciły swe pierwiastkowe cechy, choć ich znaczenie niekiedy pozostało czytelne" ${ }^{, 42}$. Dzięki internetowi łatwiej jednak do nich dotrzeć i poznać intencje oraz postawy narratorów, których opowieści wymierzone były w „obcych”, w tym także obcych politycznie. Co ważne, analizując tego typu materiały, można również wyciągać wnioski na temat intencji przyświecających współczesnym narratorom, którzy po latach od momentu ukończenia studiów zamieszczają anegdoty na ogólnodostępnych forach. Takie opowieści często mają formę memoratów, jednak ze względu na powtarzalność sytuacji i motywów, podobieństwo zdarzeń, wypowiedzi i bohaterów, w rzeczywistości okazują się one fabulatami, czyli usankcjonowanymi przez tradycję formami folkloru.

Z komentarzy towarzyszących przekazom w Sieci, także z tych przytoczonych powyżej, wyłania się nie tylko nostalgia za minionymi czasami młodości, ale także zauważalna próba swoistej heroizacji żaków, którzy pozbawieni możliwości bardziej bezpośrednich form działania mogli poprzez młodzieńcze żarty ośmieszać, a przez to osłabiać nie tylko system akademicki, ale i władzę ludową. Pośrednio wyrażano w ten sposób brak akceptacji dla tego, co działo się w kraju. Drugą zauważalną postawą w podejściu do prezentowanego materiału jest afirmacja przeszłości, bowiem w licznych przekazach nacisk położony został na samo życie studenckie ukazywane jako barwne, karnawałowe, niezależnie od panującego systemu, o czym świadczą dyskusje uczestników forum pochodzące z 2007 roku:

${ }^{40}$ [b.a.] Cud nad Wista a studium wojskowe w PRL, [w:] http://korabita.salon24.pl/527230, cud-nad-wisla-a-studium-wojskowe-w-prl

${ }^{41}$ Cyt. za: P. Łuczeczko, „Z Trobriandów do Torunia”... , op. cit., s. 102.

${ }^{42}$ W. Łysiak, op. cit., s. 8. 
No Waldi - zabawnie mówisz..... Ja leżałam na glebie i wyłam ze śmiechu, bo bezradny Major Magister naprawdę przejął się rolą i opieprzał Baryłę że wystaje - to z przodu, to z tyłu, to z góry.... A Baryła starał się być MALUTKI. I nie mógł za nic.

A pan kapitan od męskiego wojska przyszedł kiedyś na zastępstwo do babskiego i zagaił następująco: ,ja tam k... nieprzyzwyczajony jestem, k..., z babami”

Klimacik od razu się poprawił.

Z dyscypliny - trzy miałam do samiusieńkiego końca - przez tę musztrę i inne wpadki, o których dużoby. Jako jedyna w grupie do końca robiłam za szeregowca - wszyscy no wszyscy awansowali!!! Ach - Wojsko!!!

Kolega Piotrowski - no Dziwnów!!! rusz się!!!! - też mógłby wiele opowiedzieć. Nie zapomnę, jak spał z otwartymi oczami - naciągając palcami skórę, żeby się nie zamknęły. Ja myślę, że poczciwe zmarszczki, które poorały mu wysokie czoło w poprzek właśnie wtedy miały swój początek ${ }^{43}$.

[...]

I tak wyglądał cały PRL w zasadzie. Było właściwie bardziej śmiesznie niż strasznie (komedie [B]arei - to była nasza kabaretowa rzeczywistość).

Obecnie włączam TV i i chyba jest bardziej strasznie niż śmiesznie.

A to przedłużone w stanie wojennym wojsko wielu krwi napsuło... ${ }^{44}$

Tym samym anegdoty studenckie czasów PRL-u nie są tylko ,pomnikami folkloru" minionego okresu, ale dokumentem kultury, który wiele mówi zarówno o przeszłości, jak i o teraźniejszości, zwłaszcza o tym, jak sami użytkownicy internetu pamiętają oraz postrzegają anegdoty studenckie i wyłaniający się z nich obraz świata ${ }^{45}$. Dla niektórych to obraz walki z absurdami PRL-u, dla innych, co pokazują przede wszystkim starsze wpisy, m.in. te z 2007 roku, to karnawał, w którym inni dyktowali reguły życia, ale student umiał sobie $\mathrm{z}$ tym poradzićc ${ }^{46}$. Rozbieżność $\mathrm{w}$ postrzeganiu owego świata - między jego afirmacją a negacją, heroizacją a karnawalizacją - zdaje się odzwierciedlać współczesne oceny czasów PRL-u funkcjonujące w polskim społeczeństwie. Zwłaszcza, że obecnie zamieszczającymi teksty w internecie są zarówno ci, którzy studiowali w czasach PRL-u, jak i osoby znające przeszłość z drugiej połowy XX wieku jedynie ze wspomnień najbliższych. Na forach pojawiają się więc anegdoty zasłyszane (fabulaty), jak i „przeżyte” (memoraty), w obu wypadkach przedstawiające określoną wizję świata wykreowaną na podstawie własnych wspomnień lub przekazaną przez rodziców bądź starszych znajomych. W tym kontekście anegdota studencka czasów PRL-u staje się nie tylko swoistym łącznikiem w obrębie jednego pokolenia, gdyż w Sieci spotykają się osoby niegdyś razem studiujące i wspominające „wspólne dzieje”, tworząc „wirtualne sąsiedztwa" cześnie analizowane opowieści okazują się świadectwem zmieniających się ocen i postaw wobec minionej epoki oraz dowodem ciągłości kultury studenckiej.

\footnotetext{
${ }^{43}$ http://www.absolwentar.zut.edu.pl/index.php?topic=13.0 [dostęp: 20.05.2015].

${ }^{44} \mathrm{http}: / /$ www.absolwentar.zut.edu.pl/index.php?topic=13.0 [dostęp: 20.05.2015].

45 Dopełnieniem moga być zdjęcia, np. ze studium wojskowego. Zob. http:// www.absolwentar.zut.edu.pl/index.php?action=media;sa=item;in=3031 [dostęp: 20.05.2015].

${ }^{46} \mathrm{http}: / /$ www.absolwentar.zut.edu.pl/index.php?topic=13.0 [dostęp: 20.05.2015].

47 Termin zaproponowany przez Janinę Hajduk-Nijakowską. Eadem, Folklorystyczny
} nerw internetu. Wspólnotowa przestrzeń emocji i wyobraźni,,,Kultura Popularna” 2012, nr 3, s. 8. 


\section{VIOLETTA WRÓBLEWSKA \\ "MONUMENTS OF FOLKLORE": \\ STUDENTS' ANECDOTES FROM THE TIMES \\ OF THE PEOPLE'S REPUBLIC OF POLAND ON THE INTERNET}

\section{SUMMARY}

This article aims at determining to what extent the internet may facilitateresearching past forms of folklore. The source material used herein is students' anecdotes from the times of the People's Republic of Poland, which have been confronted with contemporary anecdotes. The analysis of the available texts (both published and unpublished, obtained in field research) has enabled the author to formulate the following thesis: the Internet facilitatesgetting to know not only anecdotes themselves but also their various aspects and contexts in which they appear. On the basis of the analysis of comments available on forums and discussions about the past anecdotes, one can draw interesting conclusions:Firstly, the compositionof old anecdotes reminds one of contemporary texts as it is based on the typical conflict between "one of us" (a student) and the stranger (a non-student), with the former usually winning over the latter. Secondly, the difference concerns mostly the representations of everyday life, and especially the political context, which in turn is related to the emergence of the group of "regime heroes", occasionally present also in contemporary anecdotes (the militiaman, the lecturer from a military academy). Another difference is also the absence of the theme of the fight against the dominant political system in contemporary students' anecdotes. Therefore, older students' anecdotes had both ludic and therapeutic, or compensatory, functions typical of political folklore contesting the political order. The above conclusions taking into consideration the data available on the Internet subvert MikhailD. Alekseevsky's theory that the Web only stores "monuments of folklore."

Translated by Justyna Deszcz-Tryhubczak 